\title{
Interleukin 28b Single Nucleotide Polymorphism (rs8099917) as a Predictive Factor of Response to Pegylated-IFN/Ribavirintherapy in Chronic HCV Patients
}

\author{
WAHID DOSS, M.D.*; MOHAMED ALI SABER, M.D.**; MOHAMMAD EL-SAYED, M.D.*; \\ AHMED EL DEEB, M.Sc.*** and GAMAL ESMAT, M.D.*
}

The Departments of Endemic Medicine, Hepatogastroenterology, Faculty of Medicine, Cairo University*, Biochemistry \& Molecular Biology Department, Theodor Bilharz Research Institute** and National Hepatology \& Tropical Medicine Research Institute (NHTMRI)***

\begin{abstract}
Background: For Interleukin 28b Single nucleotide polymorphism (SNP) rs8099917, the favourable T allele is associated with a higher SVR after PEG-IFN alpha/RBV therapy while the $\mathrm{G}$ allele is a risk factor for non-response.

Aim of Study: To assess the value of Interleukin 28b (SNP) rs8099917 as a predictor of SVR.

Patients and Methods: This study is a retrospective controlled study and was performed on a total number of 240 patients who were treated by PEG-IFN alpha/RBV for 48 weeks and (SNP) rs8099917 was done for the all patients.

Results: TT genotype was more prevalent in SVR group than TG and GG genotypes.

Conclusion: IL-28b single nucleotide polymorphism (SNP) rs8099917 is a strong pretreatment predictor of response to pegylated interferon and ribavirin therapy in egyptian patients chronically infected with HCV genotype 4 .
\end{abstract}

Key Words: HCV-Pegylated Interferon-Interleukin $28 b$ SNP rs8099917.

\section{Introduction}

HEPATITIS C virus (HCV) infection is a major health problem throughout the world. Egypt has the highest prevalence of HCV (10-20\%). More than $90 \%$ of $\mathrm{HCV}$ egyptian patients are of the genotype 4 variant [1]

The sustained virologic response (SVR) to PEG-IFN $\alpha$ and ribavirin therapy ranges from about 40 to $50 \%$ with genotype 1 to as high as 70 to $80 \%$ with genotypes 2 and 3, however, treatment is expensive and associated with adverse side effects [2]

Correspondence to: Dr. Wahid Doss, The Department of Endemic Medicine, Hepatogastroenterology, Faculty of Medicine, Cairo University
Due to the side-effects associated with PEGIFN $\alpha$ and ribavirin therapy, assessing predictors of response prior to treatment initiation allows the physician to select those patients most likely to achieve SVR, and thus provides information about overall management [3]. Genotype is the strongest predictor of response to antiviral treatment. Patients infected with HCV genotype 2 or 3 are much more likely to achieve SVR to PEG-IFN $\alpha$ and ribavirin therapythan patients infected with HCV genotype 1 and 4 [4].

Four genome-wide association studies found associations of many single nucleotide polymorphisms (SNPs) in the IL28B gene on chromosome 19 , which encodes type III IFN- $\gamma$, with the response to peg-IFN- $\alpha / \mathrm{RBV}$ therapy $[\mathbf{5 , 6 ]}$.

The rs8099917 SNP was the only SNP in these studies that was strongly associated with response to peg-IFN- $\alpha / \mathrm{RBV}$ therapy [7] .

Determination of single nucleotide polymorphism (SNP) rs8099917 before starting antiviral therapy may serve as a tool to decide whether to undergo treatment or wait for other therapeutic options [8].

Even with the appearance of the new antiviral drugs, Peg IFN/RBV may remain the standard of care (SOC) in HCV therapy for the next few years. So every effort is made to improve the performance of the SOC [9]. The aim of this work is to assess the value of single nucleotide polymorphism (SNP) rs8099917 as a predictor of virological response to Pegylated interferon plus ribavirin in treatment of chronic hepatitis $\mathrm{C}$ virus patients. 


\section{Subjects and Methods}

\section{Patients:}

This study was conducted on 240 Egyptian patients infected with HCV. Patients were selected from $\mathrm{HCV}$ patients who attended National Hepatology and Tropical Medicine Research Institute for receiving treatment for HCV from January 2012 up to October 2013. They were treated with Pegylated interferon a $2 \mathrm{a}$ or $2 \mathrm{~b}$ (PEG-IFN) plus ribavirin. Duration of treatment was adjusted according to their response which was determined using quantitative PCR for HCV at the 12 th and 24th week from the start of treatment. Patients who had undetectable viraemia or decrease of viral load by more than two logs (by quantitative PCR) at 12 th week from the start of treatment will continue treatment, while patients who didn't achieve that will discontinue treatment. Patients with any detected viraemia at 24 th week from the start of treatment will stop treatment. All patients signed an informed consent.

\section{Inclusion criteria:}

1- Chronically infected HCV patients aged 18 to 65 years old.

2- Serological, virological and histological diagnosis of chronic HCV.

3- Elevated ALT level above the upper limit of normal within 6 months prior to the study.

4- Patients had not been previously treated with interferon based therapy.

\section{Exclusion criteria:}

1- Decompensated liver disease.

2- Hemoglobin $<13 \mathrm{~g} / \mathrm{dL}$ for men and $<12 \mathrm{~g} / \mathrm{dL}$ for women, white blood cell count of $<3,000 / \mathrm{mm}^{3}$, absolute neutrophil count of $<1500 / \mathrm{mm}^{3}$, or platelet count of $<80,000 / \mathrm{mm}^{3}$.

3- Patients with hepatitis B surface antigen (HB$\mathrm{sAg}$ ) seropositivity or infected with the human immunodeficiency virus (HIV).

4- Active schistosomiasis.

5- Serum creatinine above the upper limit of normal.

6- Poorly controlled diabetes mellitus, hypertension, or psychiatric diseases.

7- Presence of ANA titre (antinuclear antibodies) $>1 / 160$

8- Thyroid stimulating hormone (TSH) out of normal range (0.5-5 International Units/1).

\section{Specimen collection:}

Morning blood samples were collected; $6 \mathrm{ml}$ venous samples were withdrawn and divided into 2 tubes under aseptic conditions from patients and after obtaining their written consent as follows:

- Three milliliters $(3 \mathrm{ml})$ blood were left for 10 minutes to clot and then centrifuged for 5 minutes. The serum was then separated for determination of all serological tests as well as HCV-RNA Quantitation.

- Three milliliters ( $3 \mathrm{ml})$ blood on EDTA using a sterile tube, the EDTA samples were stored at $-80^{\circ} \mathrm{C}$ to be used for molecular biology techniques.

\section{Methods:}

Laboratory Tests:

I- Routine tests:

1- Complete blood picture.

2- Liver biochemical profile: Serum bilirubin (total and direct), transaminases (ALT and AST), alkaline phosphatase, total protein, serum albumin and prothrombin time and concentration.

II- Serological tests for chronic hepatitis markers:

a- Anti-HCV EIA: The third generation Abbott HCV EIA 3.0 was used (Abbott Laboratories, Ludwigshafen, Germany).

b- HBsAg EIA: According to Abbott Monoclonal EIA (Abbott Laboratories, Ludwigshafen, Germany).

c- Anti-HBc EIA: The Abbott CORZYME commercial assay for qualitative detection of antibodies to HBV core protein ( $\operatorname{IgG}$ and $\operatorname{IgM}$ ) was used (Abbott Laboratory, Ludwigshafen, Germany and Abbott Park, II).

\section{III- HCV RNA using real time quantitative PCR Technique:}

It was done for all patients to detect the viral load. Pretreatment PCR assessment then at 12 th, 24 th, 48 th and $72^{\text {th }}$ week from start of treatment.

IV- Analysis of Interleukin 28B polymorphism by Real time PCR technique using TaqMan SNP genotyping assay:

Extraction of genomic DNA from sterile EDTA anti-coagulated blood samples was done using QIAamp DNA blood Mini kit (Qiagen, Hilden, Germany) by silica-gel spin columns. Real-time PCR allelic discrimination was designed using TaqMan SNP Genotyping Assays (Applied Biosystems)and performed on Step OneTM Real Time PCR System (Applied Biosystems, Foster City, CA), using the fluorogenic 5'nuclease with TaqMan 
minor groove binder (MGB) probes to define interleukin 28B gene SNP (rs8099917). The wild type TaqMan MGB probe was VIC labelled (Allele 1) and the mutant probe was FAM labelled (Allele 2).

The final volume of each reaction was $25 \mathrm{ul}$, consisting of 12.5ul TaqMan Universal PCR Master Mix (2X) which contained AmpliTaq-Gold DNA polymerase, $1.25 \mathrm{ul}$ assay mix (20X) contained primers and probes, $5 \mathrm{ul}$ genomic DNA, and $6.25 \mathrm{ul}$ nuclease free water. Negative control (no DNA template) was run to ensure that there was no amplification of contaminating DNA. The amplification reactions were carried out with initial hold step at $95^{\circ} \mathrm{C}$ for $10 \mathrm{~min}$ for activation of AmpliTaqGold DNA polymerase followed by 40 cycles of three-step PCR: Denaturation at $92^{\circ} \mathrm{C}$ for $15 \mathrm{sec}$, annealing at $60^{\circ} \mathrm{C}$ for $30 \mathrm{sec}$ and extension at $60^{\circ} \mathrm{C}$ for $30 \mathrm{sec}$. The fluorescence signal increases when the probe with the exact sequence match binds to the single stranded template DNA and is digested by the 5 'nuclease activity of AmpliTaq-Gold DNA polymerase. Digestion of the probe releases the fluorescent reporter dye (either FAM or VIC) from the quencher dye.

\section{V- Liver biopsy for histological assessment:}

Trans-abdominal ultrasound guided liver biopsy was done for all patients prior to starting treatment for $\mathrm{HCV}$ to assess grade of inflammation (Activity) and stage of fibrosis according to METAVIR scoring system. The stage of liver fibrosis was scored according to the METAVIR scoring system: F0 (no fibrosis), F1 (mild fibrosis: portal fibrosis without septa), F2 (moderate fibrosis: few septa), F3 (severe fibrosis: Numerous septa without cirrhosis) and F4 (cirrhosis). Inflammation was graded A0 (no activity), A1 (mild activity), A2 (moderate activity), A3 (severe activity).

\section{Statistical methods:}

Data was analyzed using PASW statistics 18. Numerical data were expressed as mean and standard deviation. Qualitative data were expressed as frequency and percentage. Chi-square test (Fisher's exact test) was used to examine the relation between qualitative variables. For quantitative data normally distributed, comparison between two groups was done using $t$-test. Comparison between 3 groups or more was done using ANOVA test. For quantitative and qualitative data not normally distributed, comparison was done using Kruskal-Wallis test. Logistic regression model was done for predictors' detection at $95 \%$ confidence level. A $p$-value $<0.05$ was considered significant.

\section{Results}

Table (1) shows all baseline demographic, histological and virological characteristics of the studied patients.

Table (1): Distribution of studied patients according to their baseline characteristics.

\begin{tabular}{llc}
\hline \multirow{2}{*}{ Variable } & \multicolumn{2}{c}{ Studied patients } \\
\cline { 2 - 3 } & Number & Percent \\
\hline Age: & & \\
$\leq 40$ & 116 & 48.3 \\
$>40$ & 124 & 51.7 \\
Total & 240 & 100 \\
Mean \pm SD & \multicolumn{2}{c}{$40.30 \pm 10.912$} \\
Gender: & & \\
Male & 172 & 71.7 \\
Female & 68 & 28.3 \\
Total & 240 \\
Degree of fibrosis: & & 100 \\
Mild (F1) & 152 & \\
Moderate - severe (F2-F3) & 88 & 63.3 \\
Total & 240 & 36.7 \\
Degree of activity: & & 100 \\
Mild (A1) & 152 & \\
Moderate - severe (A2-A3) & 88 & 63.3 \\
Total & 240 & 36.7 \\
IL 28: & & 100 \\
TG & 100 & \\
TT & 65 & 27.1 \\
GG & 75 & 31.3 \\
Total & 240 & 100 \\
\hline
\end{tabular}

The rs 8099917 allele frequency is $27.1 \%$ for TT (65 patients), $41.7 \%$ for TG (100 patients), and $31.3 \%$ for GG (75 patients). We defined the Interleukin 28b (IL28b) major allele as homozygous for the major sequence (TT) and the IL28b minor allele as homozygous (GG) or heterozygous (TG) for the minor sequence.

Statistically there was no significant correlation between response of chronic hepatitis $\mathrm{C}$ patients treated with peg-IFN/RBV and age or gender with $p$-value (0.653) and (0.403) respectively. The relation between the $\alpha$ feto protein and response to treatment was statistically non significant.

Table (2): Relation between response of chronic hepatitis C patients treated with Peg IFN/RBV and IL 28B SNP rs 8099917.

\begin{tabular}{|c|c|c|c|c|c|c|c|}
\hline & \multicolumn{2}{|c|}{ TG } & \multicolumn{2}{|c|}{$\mathrm{TT}$} & \multicolumn{2}{|c|}{ GG } & \multirow{2}{*}{ Significance } \\
\hline & $\mathrm{N}$ & $\%$ & $\mathrm{~N}$ & $\%$ & $\mathrm{~N}$ & $\%$ & \\
\hline SVR & 20 & 20 & 34 & 52.3 & 7 & 9.3 & 0.001 \\
\hline Non- responder & 80 & 80 & 31 & 47.7 & 68 & 90.7 & (HS) \\
\hline Total & 100 & 100 & 65 & 100 & 75 & 100 & \\
\hline
\end{tabular}




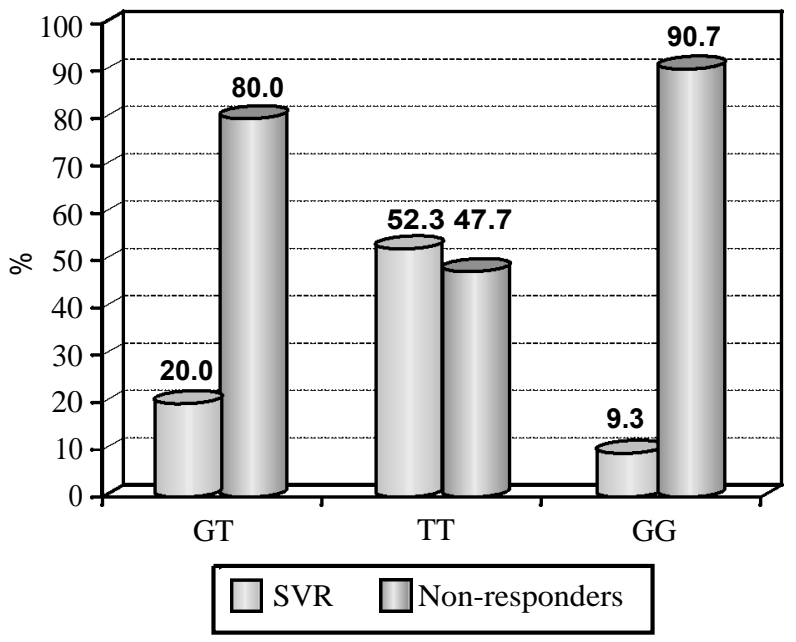

Fig. (1): Relation between response of chronic hepatitis C patients treated with Peg IFN/RBV and IL 28b SNP rs 8099917.

Genetic polymorphism in one tagging SNP located $8 \mathrm{~kb}$ upstream of IL28b gene (rs8099917) was determined by OneTM Real Time PCR System (Applied Biosystems, Foster City, CA). Homozygosity (GG) or heterozygosity (TG) of the minor sequence was defined as having the IL28b minor allele (mutant type), whereas homozygosity for the major sequence (TT) was defined as having the IL28b major allele (wild type).

Patients with TT genotype have higher SVR to treatment with pegylated interferon plus ribavirin in chronic HCV patients than other patients with TG genotype and GG genotype $(52.3 \%$ vs $20 \% \&$ $9.3 \%, p$-value $<0.001)$.

These findings suggest that IL 28b (rs8099917) has great impact on sustained virological response (SVR) to therapy with pegylated interferon plus ribavirin in chronic HCV patients.

Table (3): Predictive factors for response to peg-interferon by logistic regression model: Univariate analysis using a logistic regression model of predictive factors detection at $95 \%$ confidence level.

\begin{tabular}{lcc}
\hline Predictor & $95 \%$ CL & Significance \\
\hline IL 28b SNP rs8099917 & $0.21-0.398$ & $0.001(\mathrm{HS})$ \\
\hline
\end{tabular}

A $p$-value $<0.05$ was considered significant.

The IL 28b SNP rs8099917 was highly significant as predictors of response to treatment of patients with chronic HCV with $p$-value $<0.001$.

\section{Discussion}

Host factors including age, body weight, insulin resistance, stage of fibrosis, and compliance influence the outcome of antiviral treatment in patients with chronic HCV. Moreover, chronic HCV European or Asian patients have a higher rate of SVR than African American or Hispanic patients [10,11] reinforcing the influence of genetic host factors.

Studies have identified single nucleotide polymorphisms (SNPs) in proximity to the interleukin$28 \mathrm{~b}$ (IL-28b) gene as important predictors of treatment outcome. These findings have not only provided a new window into host responsiveness to IFN-based therapy but have also yielded insights into genetic susceptibility to chronic $\mathrm{HCV}$ infection, the molecular biology of host immunity against $\mathrm{HCV}$, and the potential for discovery of new therapeutic agents [12].

In 2009 and 2010, four independent Genomewide association studies (GWAS)on response to treatment of chronic hepatitis $\mathrm{C}$ with peg IFN- a and ribavirin were published [13-16]. Only SNPs around the IL28b gene reached significance for the association with treatment outcome. Consistently, rs12979860 C (good-response allele) versus $\mathrm{T}$ (poor-response allele) and rs8099917 T (goodresponse allele) versus $\mathrm{G}$ (poor-response allele) showed the strongest association with SVR of thus far characterized SNPs.

In the present study, the impact of rs8099917 genetic polymorphisms near the IL28b gene on response of chronic $\mathrm{HCV}$ patients to standard treatment was investigated by analyzing the association between genetic polymorphisms and sustained virological response (SVR) after administering Pegylated interferon and ribavirin.

We have demonstrated that carriers with the TT genotype of rs8099917, located $8 \mathrm{~kb}$ upstream of IL-28b, are more likely to achieve SVR with $\mathrm{HCV}$ infected egyptian patients after standard treatment.

It was found that the rate of SVR was significantly higher $(52.3 \%$ vs. $20 \%$ and $9.3 \%$ with $p<0.001)$ in patients with the IL28b major allele (TT, wild type) compared to those with the minor allele (non TT, mutant type).

Our study reconfirmed the previously reported findings in various populations around the world in a large cohort of HCV mono-infected patients with chronic hepatitis C genotype (GT) 1 [17-20] but our study included Egyptian patients who are mainly infected with HCV GT4.

Grebely J1 et al., (2010) observed that there was a difference in the impact of IL-28b polymorphism among viral genotypes (GTs). In contrast 
to GT1 and GT4 patients, the rs12979860 SNP had no impact on SVR rates in GT2/3. They have reported associations of rs 12979860 CC genotype and rs8099917 TT genotype with RVR but not SVR in patients with HCV genotype $2 / 3$ infection, implying that the $\mathrm{CC}$ genotype may be associated with relapse in their population too [21].

This observation is in agreement with observations by others Kurosaki M1 et al., [22] .

Studies of HCV genotype 2-infected European patients show that the CC genotype at rs12979860 can predict SVR, but this is largely driven by patients who do not achieve RVR [23] .

Rauch et al., [6] have also shown no effect of rs8099917 in HCV genotype 2/3-infected patients in a smaller cohortstudy.

Similarly [6], AlsoMontes-Cano et al., [17] showed no association of rs12979860 with SVR in HCV genotype 2/3-infected patients.

Stättermayer et al., (2010) Studied 102 Egyptian patients infected with HCV (GT 4) and they found that the major allele $\mathrm{T}$ was associated with significant SVR ( $p=0.0036)$, also observed that low base line viral load $(<800,000 \mathrm{IU} / \mathrm{ml})$ had significant effects on the SVR ( $p=0.0085)$ [15]. Thompson et al., [18] found that genetic polymorphisms near the IL28b gene were associated strongly with early viral kinetics during the combination therapy with PEG-IFN and ribavirin.

Toyoda H., et al., [19] observed a difference in the decrease in HCV RNA levels 24 hours after administering Peg-IFN in patients with the TT genotype compared to those with the TG/GG genotype. The rs8099917 genetic polymorphisms near the IL28b gene was an only independent factor that was associated with a decrease in HCV RNA levels 24 hours after IFN administration.

Furthermore, it was suggested that IL-28b may play a role in determining whether acute $\mathrm{HCV}$ infection leads to spontaneous clearance or chronic infection. A large study of over 1000 individuals in which the prevalence of the rs 12979860 genotype was investigated in patients who achieved spontaneous resolution and those who developed chronic $\mathrm{HCV}$ infection $[19,20]$. These studies found that individuals with the $\mathrm{C} / \mathrm{C}$ genotype had a 3 -folds greater likelihood of spontaneous HCV clearance compared to patients who had the T/C or T/T genotype.

Similar findings have been found in association with the rs8099917 polymorphism, in which the favorable T/T genotype is associated with spontaneous resolution; this relationship was also found in $\mathrm{HCV} / \mathrm{HIV}$ co-infected individuals [23-25] .

Our findings suggested that the IL28b genotype SNP rs8099917 was a useful baseline predictor of virological response which should be used for selecting the treatment regimen: Whether to treat patients with peg-IFN and RBV or to wait for more effective therapy including direct acting antiviral drugs.

On the other hand, baseline IL28b SNP rs8099917 genotype might not be suitable for determining the treatment duration in patients who started PEG-IFN/RBV therapy and whose virological response is determined because the IL28b SNP rs8099917 genotype is not useful for the prediction of relapse. The duration of therapy should be determined based on the virologicalresponse [26]

\section{Conclusion:}

IL-28bsingle nucleotide polymorphism (SNP) rs8099917 is a strong pretreatment predictor of response to pegylated interferon and ribavirin in egyptian patients chronically infected with $\mathrm{HCV}$ genotype 4.

\section{Author disclosure statement:}

No conflict of interest.

\section{References}

1- KAMAL S.M. and NASSER I.A.: Hepatitis C genotype 4: What we know and what we don't yet know.Hepatology, Apr. 47 (4): 1371-83. doi: 10.1002/hep.22127, 2008.

2- FRIED M.W1, SHIFFMAN M.L., REDDY K.R., SMITH C., MARINOS G., GONÇALES F.L. Jr., HÄUSSINGER D., DIAGO M., CAROSI G., DHUMEAUX D., CRAXI A., LIN A., HOFFMAN J. and YU J.: Peginterferon alfa2a plus ribavirin for chronic hepatitis $\mathrm{C}$ virus infection. N. Engl. J. Med., Sep. 26; 347 (13): 975-82, 2002.

3- GHANY M.G1, STRADER D.B., THOMAS D.L. and SEEFF L.B.: Diagnosis, management, and treatment of hepatitis C: An update; American Association for the Study of Liver Diseases. Hepatology, Apr. 49 (4): 1335 74. doi: 10.1002/hep.22759, 2009.

4- McCARTHY J.J1, LI J.H., THOMPSON A., SUCHINDRAN S., LAO X.Q., PATEL K., TILLMANN H.L., MUIR A.J. and McHUTCHISON J.G.: Replicated association between an IL28B gene variant and a sustained response to pegylated interferon and ribavirin. Gastroenterology. Jun;138 (7): 2307-14, 2010. doi: 10.1053/j.gastro. 2010.02.009. Epub 2010 Feb 19.

5- TANAKA Y1, NISHIDA N., SUGIYAMA M., KUROSAKI M., MATSUURA K., SAKAMOTO N., NAKAGAWA M., KORENAGA M., HINO K., HIGE S., ITO Y., MITA E., TANAKA E., MOCHIDA S., MURAWAKI Y., HONDA M., SAKAI A., HIASA Y., NISHIGUCHI S., KOIKE A., SAKAIDA I., IMAMURA M., ITO K., YANO K., MASAKI N., SUGAUCHI F., IZUMI N., 
TOKUNAGA K. and MIZOKAMI M.: Genome-wide association of IL28B with response to pegylated interferonalpha and ribavirin therapy for chronic hepatitis C. Nat. Genet, Oct. 41 (10): 1105-9, 2009. doi: 10.1038/ng.449. Epub 2009 Sep 13.

6- RAUCH A1, KUTALIK Z., DESCOMBES P., CAI T., Di IULIO J., MUELLER T., BOCHUD M., BATTEGAY M., BERNASCONI E., BOROVICKA J., COLOMBO S., CERNY A., DUFOUR J.F., FURRER H., GÜNTHARD H.F., HEIM M., HIRSCHEL B., MALINVERNI R., MORADPOUR D., MÜLLHAUPT B., WITTECK A., BECKMANN J.S., BERG T., BERGMANN S., NEGRO F., TELENTI A. and BOCHUD P.Y.: Swiss Hepatitis C Cohort Study; Swiss HIV Cohort Study.Genetic variation in IL28B is associated with chronic hepatitis C and treatment failure: A genome-wide association study. Gastroenterology, Apr. 138 (4): 1338-45, 1345.e1-7, 2010. doi: 10.1053/ j.gastro.2009.12.056. Epub 2010 Jan 11.

7- PINEDA J.A1, CARUZ A., RIVERO A., NEUKAM K., SALAS I., CAMACHO A., PALOMARES J.C., MIRA J.A., MARTÍNEZ A., ROLDÁN C., de la TORRE J. and MACÍAS J.: Prediction of response to pegylated interferon plus ribavirin by IL28B gene variation in patients coinfected with HIV and hepatitis C virus.Clin Infect Dis. 2010 Oct 1;51(7):788-95. doi: 10.1086/656235.

8- BROWN R.S. Jr.: Customizing treatment to patient populations.Nat. Clin. Pract Gastroenterol. Hepatol., Jan. 4 (Suppl 1): S3-9, 2007.

9- ESMAT G1, EL RAZIKY M., ELSHARKAWY A., SABRY D., HASSANY M., AHMED A., ASSEM N., EL KASSAS M. and DOSS W.: Impact of vitamin D supplementation on sustained virological response inchronic hepatitis $\mathrm{C}$ genotype 4 patients treated by pegylated interferon/rib-avirin. J. Interferon Cytokine Res., Jan. 35(1):49-54. doi: 10.1089/jir.2014.0060, 2015.

10- YAN K.K1, GUIRGIS M., DINH T., GEORGE J., DEV A., LEE A. and ZEKRY A.: Treatment responses in Asians and Caucasians with chronic hepatitis $\mathrm{C}$ infection. World J. Gastroenterol., Jun. 7; 14 (21): 3416-20, 2008.

11- MUIR A.J1, BORNSTEIN J.D. and KILLENBERG P.G.: Atlantic Coast Hepatitis Treatment Group. Peginterferon alfa- $2 b$ and ribavirin for the treatment of chronic hepatitis $\mathrm{C}$ in blacks and non-Hispanic whites. N. Engl. J. Med., May 27; 350 (22): 2265-71, 2004.

12- GONZALEZ S.A1 and KEEFFE E.B.: IL-28B As a Predictor of Sustained Virologic Response in Patients with Chronic Hepatitis C Virus Infection. Gastroenterol. Hepatol. (N Y), Jun. 7 (6): 366-73, 2011.

13- GE D1, FELLAY J., THOMPSON A.J., SIMON J.S., SHIANNA K.V., URBAN T.J., HEINZEN E.L., QIU P., BERTELSEN A.H., MUIR A.J., SULKOWSKI M., McHUTCHISON J.G. and GOLDSTEIN D.B.: Genetic variation in IL28B predicts hepatitis C treatment-induced viral clearance. Nature, Sep. 17; 461 (7262): 399-401, 2009. doi: 10.1038/nature08309. Epub 2009 Aug 16.

14- SUPPIAH V1, MOLDOVAN M., AHLENSTIEL G., BERG T., WELTMAN M., ABATE M.L., BASSENDINE M., SPENGLER U., DORE G.J., POWELL E., RIORDAN S., SHERIDAN D., SMEDILE A., FRAGOMELI V., MÜLLER T., BAHLO M., STEWART G.J., BOOTH D.R. and GEORGE J.: IL28B is associated with response to chronic hepatitis $\mathrm{C}$ interferon-alpha and ribavirin therapy. Nat. Genet., Oct. 41 (10): 1100-4, 2009. doi: 10. 103 8/ng.447. Epub 2009 Sep 13.

15- STÄTTERMAYER A.F1, STAUBER R., HOFER H., RUTTER K., BEINHARDT S., SCHERZER T.M., ZINOBER K., DATZ C., MAIERON A., DULIC-LAKOVIC E., KESSLER H.H., STEINDL-MUNDA P., STRASSER M., KRALL C. and FERENCI P.: Impact of IL28B genotype on the early and sustained virologic response in treatment-naïve patients with chronic hepatitis C. Clin. Gastroenterol. Hepatol., Apr. 9 (4): 344-350.e2, 2011. doi: 10.1016/j.cgh.2010.07.019. Epub 2010 Aug 20.

16- MANGIA A., THOMPSON A.J., SANTORO R., et al.: An IL28B polymorphism determines treatment response of hepatitis $\mathrm{C}$ virus genotype 2 or 3 patients who do not achieve a rapid virologic response. Gastroenterology, 139: 821-7, 2010.

17- MONTES-CANO M.A1, GARCÍA-LOZANO J.R., ABAD-MOLINA C., ROMERO-GÓMEZ M., BARROSO N., AGUILAR-REINA J., NÚÑEZ-ROLDÁN A., GONZÁ-LEZ-ESCRIBANO M.F.: Interleukin-28B genetic variants and hepatitis virus infection by different viral genotypes. Hepatology, Jul. 52 (1): 33-7. doi: 10.1002/hep.23624, 2010.

18- THOMPSON A.J1, MUIR A.J., SULKOWSKI M.S., GE D., FELLAY J., SHIANNA K.V., URBAN T., AFDHAL N.H., JACOBSON I.M., ESTEBAN R., POORDAD F., LAWITZ E.J., McCONE J., SHIFFMAN M.L., GALLER G.W., LEE W.M., REINDOLLAR R., KING J.W., KWO P.Y., GHALIB R.H., FREILICH B., NYBERG L.M., ZEUZEM S., POYNARD T., VOCK D.M., PIEPER K. S., PATEL K., TILLMANN H.L., NOVIELLO S., KOURY K., PEDICONE L.D., BRASS C.A., ALBRECHT J.K., GOLDSTEIN D.B. and McHUTCHISON J.G.: Interleukin-28B polymorphism improves viral kinetics and is the strongest pretreatment predictor of sustainedvirologic response in genotype 1 hepatitis $\mathrm{C}$ virus. Gastroenterology, Jul. 139 (1): 120-9.e18, 2010. doi: 10.1053/j.gastro. 2010.04.013. Epub 2010 Apr 24.

19- TOYODA H1, KUMADA T., TADA T., KAWAGUCHI T., MURAKAMI Y. and MATSUDA F.: Impact of genetic polymorphisms near the IL28B gene and amino acid substitutions in the hepatitis virus coreregion on interferon sensitivity/resistance in patients with chronic hepatitis C. J. Med. Virol., Jul. 83 (7): 1203-11. doi: 10.1002/ jmv.22092, 2011.

20- THOMAS D.L1, THIO C.L., MARTIN M.P., QI Y., GE D., O'HUIGIN C., KIDD J., KIDD K., KHAKOO S.I., ALEXANDER G., GOEDERT J.J., KIRK G.D., DONFIELD S.M., ROSEN H.R., TOBLER L.H., BUSCH M.P., MCHUTCHISON J.G., GOLDSTEIN D.B. and CARRINGTON M.: Genetic variation in IL28B and spontaneous clearance of hepatitis C virus. Nature, Oct. 8; 461 (7265): 798-801. doi: 10.1038/nature08463, 2009.

21- GREBELY J1, PETOUMENOS K., HELLARD M., MATTHEWS G.V., SUPPIAH V., APPLEGATE T., YEUNG B., MARKS P., RAWLINSON W., LLOYD A.R., BOOTH D., KALDOR J.M., GEORGE J. and DORE G.J.: ATAHC Study Group. Potential role for interleukin28B genotype in treatment decision-making in recent hepatitis $C$ virus infection. Hepatology, Oct. 52 (4): 1216-24. doi: 10.1002/ hep.23850, 2010.

22- KUROSAKI M1, TANAKA Y., NISHIDA N., SAKAMOTO N., ENOMOTO N., HONDA M., SUGIYAMA M., 
MATSUURA K., SUGAUCHI F., ASAHINA Y., NAKAGAWA M., WATANABE M., SAKAMOTO M., MAEKAWA S., SAKAI A., KANEKO S., ITO K., MASAKI N., TOKUNAGA K., IZUMI N. and MIZOKAMI M.: Pre-treatment prediction of response to pegylatedinterferon plus ribavirin for chronic hepatitis $C$ using genetic polymorphism in IL28B and viral factors. J. Hepatol., Mar. 54 (3): 439-48, 2011. doi: 10.1016/j.jhep. 2010.07.037. Epub 2010 Sep 19.

23- MANNS M.P1, McHUTCHISON J.G., GORDON S.C., RUSTGI V.K., SHIFFMAN M., REINDOLLAR R., GOODMAN Z.D., KOURY K., LING M. and ALBRECHT J.K.: Peginterferon alfa-2b plus ribavirin compared with interferon alfa- $2 b$ plus ribavirin for initial treatment of chronic hepatitis C: A randomisedtrial. Lancet, Sep. 22; 358 (9286): 958-65, 2001.

24- SHIFFMAN M.L., SUTER F., BACON B.R., NELSON D., HARLEY H., SOLA R., et al.: Peginterferon alfa-2a and ribavirin for 16 or 24 weeks in HCV genotype 2 or 3. N. Engl. J. Med., 357: 124-134, 2007.

25- ZEUZEM S1, HULTCRANTZ R., BOURLIERE M., GOESER T., MARCELLIN P., SANCHEZ-TAPIAS J., SARRAZIN C., HARVEY J., BRASS C. and ALBRECHT J.: Peginterferon alfa-2b plus ribavirin for treatment of chronic hepatitisC in previously untreated patients infectedwith HCV genotypes 2 or 3. J. Hepatol., Jun. 40 (6): 993-9, 2004.

26- JACOBSON I.M1, BROWN R.S. Jr., FREILICH B., AFDHAL N., KWO P.Y., SANTORO J., BECKER S. WAKIL A.E., POUND D., GODOFSKY E., STRAUSS R., BERNSTEIN D., FLAMM S., PAULY M.P., MUKHOPADHYAY P., GRIFFEL L.H. and BRASS C.A.: WIN-R Study Group. Peginterferon alfa-2b and weight-based or flat-dose ribavirin in chronic hepatitis $\mathrm{C}$ patients: A randomized trial.Hepatology, Oct. 46 (4): 97181, 2007.

\title{
استخدام النمط الجينى للنيكوليوتيد الفردى متعدد الأشكال (ربس كوسيلة تنبؤية للاستجابة للانترفيرون طويل الهفوليدول والريبيافيرين

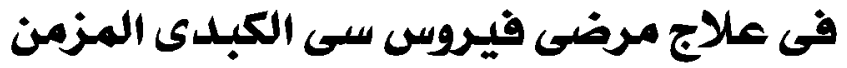

\author{
الخلفية: بالنسبة للنمط الجينى للنيكوليوتيد الفردى متعدد الأشكال (رس

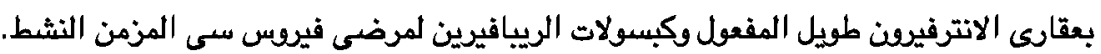

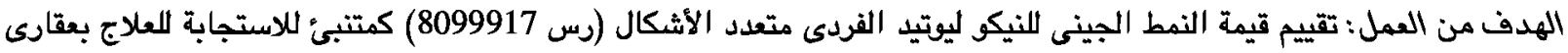

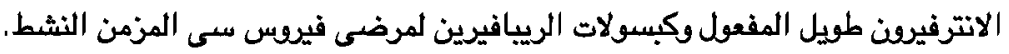 \\ الهرضى والطرق: هذه الدراسة عبارة عن دراسة بأثر رجعى تم إجراؤها على إجمالى •ع مريضاً تم علاجهم بعقارى الانترفيرون طويل

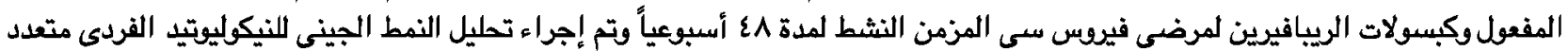

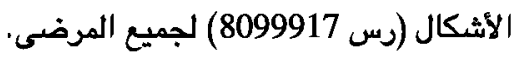 \\ النتائج:كان النمط الجينى TT أكثر انتشاراً فى مجموعة المرضى المستجيبين أكثر من الأنماط الجينية الأخرى TG وGG.

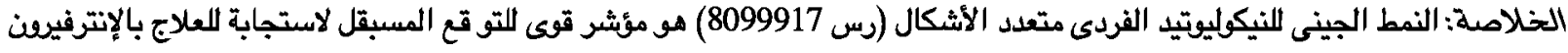

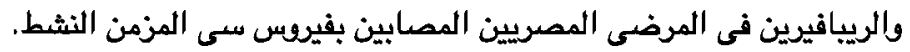

